\title{
Antecedents of Word-of-Mouth Communication and Purchase Intention on Facebook
}

\author{
Bogdan Anastasiei \\ University "Alexandru loan Cuza" Iaşi, Romania \\ E-mail:abo28@yahoo.com \\ Ana Raluca Chiosa \\ University "Alexandru loan Cuza" Iaşi, Romania \\ E-mail: ana_raluca_c@yahoo.com
}

Received: 2 November 2018/ Revised: 4 December 2018/ Accepted: 7 December 2018/Published online: 21 December 2018

\begin{abstract}
More and more business customers use social media to express their opinions about products, services and brands. This study aims to make a step further in understanding consumer engagement in electronic word of mouth (eWOM) on Facebook and its impact on recommending and purchasing products. To test our conceptual framework, structural equation modeling techniques have been applied to data collected through a self-administrated survey addressed to 640 Facebook users from Romania. Our model shows that Facebook's perceived usefulness influences customer brand engagement, which in turn has an important effect on the intention to purchase the brand and recommend it to others (word of mouth). Therefore, people who use Facebook as a source of information about products and services are top eWOM providers. A brand that seeks to build authority on Facebook should look for eWOM providers, convert them into fans and "feed" them with attention-grabbing information that is worth spreading. This way, most of the fans will provide free word-of-mouth advertising, becoming true brand ambassadors. Our study has established that Facebook's perceived usefulness not only engages online users with brands, but also makes this medium a perfect eWOM tool: it builds trust in friends' recommendations, and eventually, makes the users sincere supporters of the brands they like.
\end{abstract}

JEL classification: M31, M37

Keywords: electronic word of mouth, brand engagement, referral intention, recommendations, purchase intention, social media.

\section{INTRODUCTION}

Word of mouth (abbreviated WOM) as a social phenomenon has existed for a very long time. Consumers have always valued direct opinions (Bughin, Doogan, \& Vetvik, 2010) and talked about their experiences related to products, services and brands. WOM has always influenced consumer behavior but its meaning and importance have increased with the internet. Online communities are very effective communication channels, where positive or negative 
opinions regarding products and services in the market spread very rapidly and influence the purchasing decisions of thousands, or maybe even millions of consumers, in some cases. If in the traditional word-of-mouth process a person talks to only one other person, or at most 3-4 persons simultaneously, on the Internet, he or she can convey information to thousands of friends or fans in a few seconds.

A social network is a set of people or groups of people with some pattern of contacts or interactions between them (Newman, 2003). Only the Facebook social network has over 7,200,000 users in Romania, representing about $35 \%$ of the country's total population and about $75 \%$ of the number of internet surfers. All those users engage daily in an impressive communication activity, consisting of tens of millions of posts, likes and shares. A big part of these messages contains information, opinions and recommendations for various products and brands in the Romanian market.

Social media have a dramatic influence on every stage of the consumer decision-making process including information acquisition, brand awareness, purchase behavior, and post-purchase communication and evaluation, as well as general opinions and attitude formation (Mangold \& Faulds, 2009). Some say social media marketing is electronic word-of-mouth marketing, since using these platforms can reveal not only the positive aspects, but also unsatisfactory services, public blunders and corporate rule breaking, which brings them trust (Champoux, Durgee, \& McGlynn, 2012). Consumer-created information is likely to be more credible than seller-created information because credibility of information is often positively related to the trustworthiness of the information source (Wilson \& Sherrell, 1993). Thus WOM is perceived as more trustworthy and more relevant, and can significantly reduce consumer resistance because it originates from the experiences of other consumers (Bickart \& Schindler, 2001).

Electronic word of mouth in social network sites (SNSs) can be examined through three aspects - opinion seeking, opinion giving and opinion passing (Chu \& Kim, 2011) - and it is an important marketing strategy that affects internet user behaviors (Park \& Kim, 2008), due to its characteristics such as speed of diffusion, persistence and accessibility and greater observability (Cheung \& Lee, 2012).

\section{LITERATURE REVIEW}

Facebook is a network for sharing interests, events and ideas, and for connecting people, but this paper seeks to investigate whether it is also a useful source of electronic word of mouth, thus influencing online users in making purchase decisions. Previous research showed two consumer segments that find seeking product recommendation on Facebook pleasant and enjoyable (Chiosa \& Anastasiei, 2015).

The aim of this study is to examine the influence of Facebook's perceived usefulness on both eWOM propensity and purchase intention. We hypothesize that this influence acts through the medium of two other variables: the level of trust in the recommendations received from Facebook friends and online brand engagement. Our conceptual model is presented in Figure 1. 
Figure 1.

Causal model

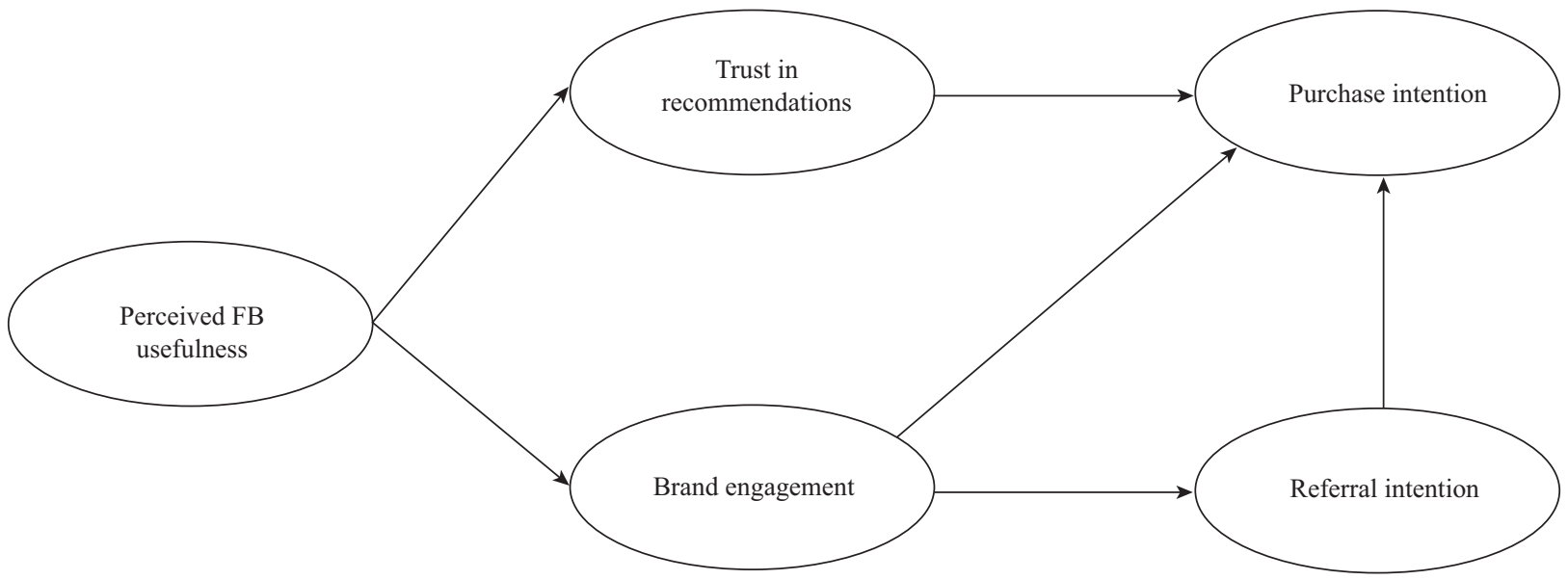

\subsection{Perceived Usefulness}

Online environments are information-based service environments that are fundamentally linked with technology and technological innovation (Morgan-Thomas \& Veloutsou, 2013) and the decision-making process of consumers is influenced by the information they receive (Fan, Miao, Fang, \& Lin, 2013).

The technology acceptance model (TAM) has identified the role of the perceived usefulness and perceived ease-of-use constructs in the information technology adoption process (Karahanna \& Straub, 1999), suggesting that individuals will use computer technology if they believe it will result in positive outcomes (Igbaria \& Iivari, 1995). In the application of information systems, the TAM has been successfully used by many researchers to predict behavioral intent to use information technology. Perceived usefulness is defined as "the degree to which a person believes that using a particular system would enhance his or her job performance" (Davis, 1989).

New communications technologies, like Facebook, have an impact on social life. According to Chu and Kim (2011), online consumers' search for brand information, creation of content and willingness to share content with others are extremely useful in increasing brand engagement and relevance. At the same time, the user's perception of the usefulness of the interactions with an online brand has implications for their attitude and behavior (Flavian, Guinalíu, \& Gurrea, 2006). Cho and Sagynov (2015) found that perceived usefulness also has a significant effect on customers' behavioral intention to shop online. Based on these facts, we have formulated the following research hypotheses:

H1. Higher perceived usefulness of FB will result in higher trust in FB friends' recommendations.

H2. Higher perceived usefulness of FB will result in higher brand engagement on FB.

\subsection{Perceived Trust in Recommendations}

Trust is considered a vital factor affecting online consumer activities, such as the acceptance of others' advice (McKnight, Choudhury, \& Kacmar, 2002) and word of mouth is often perceived as originating from a less biased, more trustworthy source (Turri, Smith, \& Kemp, 2013). Trust on Facebook can be understood as interpersonal trust between the trustor and his/her Facebook friends (Lu, Zhao, \& Wang, 2010). Okazaki, Rubio and Campo's (2013) study findings suggest that consumer trust in user-generated brand recommendations - which is the reliability, usefulness, 
and effect of brand recommendations made by friends on Facebook and willingness to rely on them (Soh, Reid, \& King, 2009) - can be better understood in relation to an individual's intention to trust his or her Facebook friends who distribute such recommendations.

Consumers care about the correctness and usefulness of eWOM, and good content quality increases their willingness to trust eWOM (Awad \& Ragowsky, 2008). It was also shown that establishing trust in the online environment positively impacts consumers' attitudes and purchasing intentions (Hassanein \& Head, 2007) and trust moderates the impact of eWOM on purchase intention (See-To \& Ho, 2014). This led us to the following hypothesis:

H3. Perceived trust in recommendations on FB positively influences purchase intention.

\subsection{Brand Engagement}

Most brands struggle to engage with their fans on Facebook, pursuing the goal based on the engagement metrics, such as "talking about it". Brand engagement is important because it is a strong predictor of brand loyalty (Keller, 2001) and interactive marketing communication can encourage learning, teaching, expression of commitment, and observation of brand loyalty amongst consumers (Keller, 2009). Some researchers have argued that the "like" button indicates the popularity of a message by displaying the number of people who liked the message and encourages user engagement (De Vries, Gensler, \& Leeflang, 2012), so liking a brand message is a form of brand engagement in the social media context (Schultz \& Peltier, 2013). Hutter, Hautz, Dennhardt and Füller (2013) showed that engagement with a Facebook fanpage has positive effects on consumers' brand awareness, WOM activities and purchase intention.

According to Malciute and Chrysochou (2013), the concept of engagement comprises three distinct dimensions: behavioral engagement (actions), emotional engagement (feelings) and cognitive engagement (thoughts). The authors tested the concept of customer engagement in an empirical setting, providing evidence that there is a relationship between customer brand engagement on social media, behavioral brand loyalty and word of mouth. An increased level of behavioral engagement will lead to the development of behavioral brand loyalty (which influences the propensity of a customer to repurchase the brand), while the level of emotional engagement will influence a customer's intention to recommend the brand (spreading word of mouth). These previous findings suggested the following hypotheses:

H4. Brand engagement on FB positively influences eWOM referral intentions.

H5. Brand engagement on FB positively influences purchase intention.

\section{4. (eWOM) Referral Intentions}

Social media empowers consumers to easily share and receive information about products from other online consumers (Liang, Ho, Li, \& Turban, 2011). The content characteristics, like review valence and argumentation style, make online consumer reviews a useful source of information before buying (Willemsen, Neijens, Bronner, \& De Ridder, 2011). The study of Pöyry, Parvinen and Malmivaara (2013) distinguishes between consumers' hedonic and utilitarian motivations for using company-hosted Facebook pages and relates them to two types of community usage behavior: browsing and participation. Akar and Topcu (2011) argued that social media users rely on the "share" button to convey the word of mouth, and the results obtained by Hamouda and Tabbane (2013) indicated that the attitude towards the product is a full mediating variable between purchase intention and eWOM evaluation. 


\subsection{Purchase Intention}

Purchase intention is often used as an effectiveness measure to anticipate a response behavior (Morwitz, Steckel, \& Gupta, 2007). People more often rely on information that comes from social media interactions (like that shared on Facebook) when making purchase decisions. Positive WOM and eWOM play an important role in increasing customers' purchase intentions (Jeong \& Jang, 2011). These aspects lead us to the following hypothesis:

H6. eWOM referral intentions have a positive effect on purchase intention.

\section{DATA AND METHODS}

\subsection{Data Collection}

A self-administrated questionnaire was addressed to a sample of Facebook account holders from Romania $(\mathrm{N}=640)$. The sampling method used was convenience sampling. The sample comprised $69 \%$ of female and $31 \%$ of male subjects, of ages ranged from 19 to $46(\mathrm{M}=21.43$, $\mathrm{SD}=2.34)$.

\subsection{Measures}

The measurement scales were adopted from the sources mentioned in Table 1. All the individual items used a seven-point Likert scale, rating from 1 (strongly disagree) to 7 (strongly agree).

\section{Table 1}

Measurement scales

\begin{tabular}{|c|c|c|}
\hline Items & Scales & Authors \\
\hline Perceived usefulness & $\begin{array}{l}\text { Seeking product recommendations on Facebook is useful } \\
\text { to me. } \\
\text { Seeking product recommendations on Facebook makes } \\
\text { me more efficient. } \\
\text { Seeking product recommendations on Facebook makes } \\
\text { my life easier. }\end{array}$ & $\begin{array}{l}\text { Davis } \\
\text { Alghamdi, Aldridge, } \\
\text { \& Long }\end{array}$ \\
\hline $\begin{array}{l}\text { Perceived trust } \\
\text { in recommendations }\end{array}$ & $\begin{array}{l}\text { I think that product recommendations from my online friends } \\
\text { on Facebook are credible. } \\
\text { I trust product recommendations from my online friends on } \\
\text { Facebook. } \\
\text { I believe that product recommendations from my online } \\
\text { friends on Facebook are trustworthy. }\end{array}$ & $\begin{array}{l}\text { Hsiao, Chuan-Chuan } \\
\text { Lin, Wang, Lu \& Yu } \\
\text { Alghamdi, Aldridge } \\
\text { \& Long }\end{array}$ \\
\hline Brand engagement & $\begin{array}{l}\text { I like to talk about brands that are advertised on Facebook. } \\
\text { I am always interested in learning more about brands that are } \\
\text { present online. } \\
\text { I would be interested in receiving communications from a } \\
\text { brand via Facebook. } \\
\text { I accept communications from brands providing they seek my } \\
\text { permission. } \\
\text { I am proud to let others know which brands I affiliate with via } \\
\text { Facebook. } \\
\text { I like to browse through Facebook pages related to brands. } \\
\text { Compared to other people, I closely follow news about } \\
\text { brands. }\end{array}$ & Keller \\
\hline
\end{tabular}




\begin{tabular}{|c|c|c|}
\hline Items & Scales & Authors \\
\hline Referral intentions & $\begin{array}{l}\text { How likely is it that you would share a Facebook } \\
\text { advertisement with others if it offers a discount or coupon for } \\
\text { a particular product? } \\
\text { How likely is it that you would share a Facebook post with } \\
\text { others if you see one about a product that you think would } \\
\text { be useful to someone you know? } \\
\text { How likely is it that you would share a Facebook post with } \\
\text { others if you see one that focuses on how easy a product } \\
\text { is to use? } \\
\text { How likely is it that you would share a Facebook post with } \\
\text { others if you see one that focuses on a specific problem or } \\
\text { issue that may be experienced by someone you know? } \\
\text { How likely is it that you would share a Facebook post with } \\
\text { others if you see one that focuses on the benefits of a product } \\
\text { or service? } \\
\text { How likely is it that you would share a Facebook post with } \\
\text { others if you see one that focuses on how to better deal with } \\
\text { a specific problem or issue? } \\
\text { How likely is it that you would share a Facebook post with } \\
\text { others if you see one that mentions how other people are } \\
\text { getting good results from a product? }\end{array}$ & $\begin{array}{l}\text { Smith, Coyle, } \\
\text { Lightfoot \& Scott }\end{array}$ \\
\hline Purchase intention & $\begin{array}{l}\text { I am likely to buy products that I see advertised on Facebook. } \\
\text { I am likely to buy products that I see other consumers talking } \\
\text { about on Facebook. } \\
\text { I am likely to buy products that I see on Facebook if the price } \\
\text { is appealing. } \\
\text { I am likely to buy products that I see on Facebook if the } \\
\text { delivery period is satisfactory. } \\
\text { I am likely to buy a product that I see on Facebook if it is } \\
\text { a brand I know and trust. } \\
\text { I am likely to buy a product that I see on Facebook if it is } \\
\text { a new and exciting product. } \\
\text { I am likely to buy a product that I see on Facebook if it is an } \\
\text { upgrade to a product I already have. }\end{array}$ & $\begin{array}{l}\text { Campbell, Ferraro } \\
\text { \& Sands }\end{array}$ \\
\hline
\end{tabular}

\section{RESULTS}

Data analysis followed the two-step approach of SEM (Anderson \& Gerbing, 1988). The first step involves testing the constructs for reliability and validity (measurement model) and the second step involves testing the relationships between these constructs (structural model).

\subsection{Measurement Model}

Our goal at the first stage was to investigate the relationships between each construct and its individual items to determine the items that would be retained for the measurement model. We started by performing an exploratory factor analysis using IBM SPSS (version 21) with a view to detecting the items that presented important cross-loadings and removing them from the analysis. The exploratory factor analysis procedure used the maximum likelihood extraction method and the Varimax rotation method. The Kaiser-Meyer-Olkin indicator for the EFA model was 0.932, while Bartlett's test of sphericity was statistically significant $(\mathrm{p}<0.01)$. Therefore, this model had a very good sample adequacy. No individual items presented significant cross-loadings; in consequence, all the items were kept for the measurement model. 
The measurement model was created using the confirmatory factor analysis in IBM AMOS, version 21. Five constructs and twenty-seven items were entered in this model. To evaluate its goodness-of-fit we used the following cutoff values: for the root mean square error of approximation (RMSEA) -0.08 , for the comparative fit index (CFI) -0.900 , for the Tuckey-Lewis index (TLI) -0.900 , for the standardized root mean square residual (SRMR) -0.08 , for the $\chi^{2} / \mathrm{df}$ ratio - between 1 and 5. Furthermore, we computed three indicators to determine the construct reliability and validity: Cronbach's alpha, the composite reliability and the average variance extracted (AVE). The main characteristics of the measurement model are presented in Table 2.

Table 2

Measurement model key indicators

\begin{tabular}{|c|c|c|c|c|c|c|}
\hline Constructs and items & $\begin{array}{l}\text { Standardized } \\
\text { loading }\end{array}$ & $\begin{array}{c}\text { CR } \\
\text { (t-value) }\end{array}$ & SE & $\alpha$ & $\begin{array}{l}\text { Composite } \\
\text { reliability }\end{array}$ & AVE \\
\hline Perceived usefulness & - & - & - & 0.861 & 0.730 & 0.567 \\
\hline $\begin{array}{l}\text { Looking for recommendations } \\
\text { on Facebook is useful to me }\end{array}$ & 0.785 & - & - & - & - & - \\
\hline $\begin{array}{l}\text { Looking for recommendations } \\
\text { on Facebook makes me efficient }\end{array}$ & 0.912 & 23.734 & 0.045 & - & - & - \\
\hline $\begin{array}{l}\text { Looking for recommendations } \\
\text { on Facebook makes my life easier }\end{array}$ & 0.784 & 21.133 & 0.045 & - & - & - \\
\hline Trust in recommendations & & - & - & 0.884 & 0.798 & 0.635 \\
\hline $\begin{array}{l}\text { The recommendations from my online } \\
\text { friends are trustworthy }\end{array}$ & 0.889 & - & - & - & - & - \\
\hline $\begin{array}{l}\text { I confide in the recommendations from } \\
\text { my online friends }\end{array}$ & 0.892 & 28.004 & 0.036 & - & - & - \\
\hline $\begin{array}{l}\text { The recommendations I get from my } \\
\text { Facebook friends are reliable }\end{array}$ & 0.770 & 23.344 & 0.039 & - & - & - \\
\hline Brand engagement & - & - & - & 0.913 & 0.789 & 0.469 \\
\hline $\begin{array}{l}\text { I am always interested in finding } \\
\text { out more about online brands }\end{array}$ & 0.789 & - & - & - & - & - \\
\hline $\begin{array}{l}\text { I like to talk about the brands that are } \\
\text { advertised on Facebook }\end{array}$ & 0.795 & 21.858 & 0.045 & - & - & - \\
\hline $\begin{array}{l}\text { I would be interested in getting } \\
\text { information from brands through } \\
\text { Facebook }\end{array}$ & 0.742 & 23.781 & 0.041 & - & - & - \\
\hline $\begin{array}{l}\text { I accept promotional messages from } \\
\text { brands if they ask for my permission } \\
\text { first }\end{array}$ & 0.636 & 16.664 & 0.055 & - & - & - \\
\hline $\begin{array}{l}\text { I am proud to let others know } \\
\text { the brands that I like on Facebook }\end{array}$ & 0.739 & 19.960 & 0.048 & - & - & - \\
\hline $\begin{array}{l}\text { I like to look for information about } \\
\text { brands on Facebook }\end{array}$ & 0.863 & 24.294 & 0.047 & - & - & - \\
\hline $\begin{array}{l}\text { Compared to other people, I closely } \\
\text { follow the news about brands }\end{array}$ & 0.923 & 22.858 & 0.047 & - & - & - \\
\hline Referral intention & - & - & - & 0.937 & 0.809 & 0.433 \\
\hline $\begin{array}{l}\text { I share on Facebook a post that } \\
\text { presents the benefits of a product } \\
\text { or service }\end{array}$ & 0.905 & - & - & - & - & - \\
\hline
\end{tabular}




\begin{tabular}{|c|c|c|c|c|c|c|}
\hline Constructs and items & $\begin{array}{l}\text { Standardized } \\
\text { loading }\end{array}$ & $\begin{array}{c}\mathrm{CR} \\
\text { (t-value) }\end{array}$ & $\mathrm{SE}$ & $\alpha$ & $\begin{array}{l}\text { Composite } \\
\text { reliability }\end{array}$ & AVE \\
\hline $\begin{array}{l}\text { I share on Facebook a post about } \\
\text { a product that could be useful to others }\end{array}$ & 0.817 & 28.649 & 0.033 & - & - & - \\
\hline $\begin{array}{l}\text { I share on Facebook a post that shows } \\
\text { how easy it is to use a product }\end{array}$ & 0.860 & 32.074 & 0.030 & - & - & - \\
\hline $\begin{array}{l}\text { I share on Facebook a post that } \\
\text { presents a problem experienced } \\
\text { by someone I know }\end{array}$ & 0.798 & 27.440 & 0.033 & - & - & - \\
\hline $\begin{array}{l}\text { I share on Facebook an ad that } \\
\text { contains a discount or a voucher } \\
\text { for a product }\end{array}$ & 0.710 & 22.025 & 0.037 & - & - & - \\
\hline $\begin{array}{l}\text { I share on Facebook a post that } \\
\text { presents a way to solve a problem }\end{array}$ & 0.873 & 32.875 & 0.030 & - & - & - \\
\hline $\begin{array}{l}\text { I share on Facebook an ad that reveals } \\
\text { how other people benefitted from } \\
\text { a product }\end{array}$ & 0.818 & 28.804 & 0.037 & - & - & - \\
\hline Purchase intention & - & - & - & 0.913 & 0.797 & 0.445 \\
\hline $\begin{array}{l}\text { I will buy products I see on Facebook } \\
\text { if they have a good price }\end{array}$ & 0.828 & - & - & - & - & - \\
\hline $\begin{array}{l}\text { I will buy products that others talk } \\
\text { about on Facebook }\end{array}$ & 0.719 & 19.582 & 0.041 & - & - & - \\
\hline $\begin{array}{l}\text { I will buy products whose advertising } \\
\text { I see on Facebook }\end{array}$ & 0.707 & 19.139 & 0.040 & - & - & - \\
\hline $\begin{array}{l}\text { I will buy products I see on Facebook } \\
\text { if the delivery time is convenient }\end{array}$ & 0.805 & 28.401 & 0.035 & - & - & - \\
\hline $\begin{array}{l}\text { I will buy a product I see on Facebook } \\
\text { if it is a brand I know and trust }\end{array}$ & 0.739 & 19.618 & 0.048 & - & - & - \\
\hline $\begin{array}{l}\text { I will buy products I see on Facebook } \\
\text { if they are new and interesting }\end{array}$ & 0.863 & 22.361 & 0.043 & - & - & - \\
\hline $\begin{array}{l}\text { I will buy products I see on Facebook } \\
\text { if they are better versions of the } \\
\text { products I already have }\end{array}$ & 0.759 & 20.756 & 0.048 & - & - & - \\
\hline
\end{tabular}

All the factor loadings are statistically significant $(C R>1.96)$ and their standardized values are greater than 0.50 , which means that all our constructs are very well explained by their individual items. Moreover, all the goodness-of-fit indicators for the measurement model meet the cutoff values: $\chi^{2}(307)=919.289, \mathrm{p}<0.01, \chi^{2} / \mathrm{df}=2.994, \mathrm{RMSEA}=0.056, \mathrm{CFI}=0.953$, TLI $=0.946$, $\mathrm{SRMR}=0.045$.

We can also notice that our factors have good internal consistency (the reliability indicators are higher than 0.70 ). The average variance extracted is smaller than 0.5 for three factors, which poses a problem of convergent validity. According to Ping (2009), an AVE slightly below 0.5 could be acceptable is some cases if this does not generate major discriminant validity problems and if the model parameters remain significant even at higher significance requirements. As seen in Table 2, the t-values for all path coefficients are much greater than 1.96, so the coefficients are significant at very low $p$ values $(\mathrm{p}<0.001)$. In other words, the coefficients are stable despite low AVEs. As for the discriminant validity, we assessed it by comparing the AVEs with the squared inter-factor correlations, as indicated by Fornell and Larker (1981). As one can notice in Table 3, 
even a small average variance extracted is higher than most squared correlations. This denotes good discriminant validity.

Table 3

Average variance extracted and squared correlations between latent variables

$\begin{array}{lccccc}\text { Perceived usefulness } & \begin{array}{c}\text { Perceived } \\ \text { usefulness }\end{array} & \begin{array}{c}\text { Trust in } \\ \text { recommendations }\end{array} & \begin{array}{c}\text { Brand } \\ \text { engagement }\end{array} & \begin{array}{c}\text { Referral } \\ \text { intentions }\end{array} & \begin{array}{c}\text { Purchase } \\ \text { intentions }\end{array} \\ \text { Trust in recommendations } & 0.567 & 0.22 & \mathbf{0 . 6 3 5} & & \\ \text { Brand engagement } & 0.40 & 0.23 & \mathbf{0 . 4 6 9} & & \\ \text { Referral intentions } & 0.12 & 0.12 & 0.30 & \mathbf{0 . 4 3 3} & \\ \text { Purchase intentions } & 0.24 & 0.21 & 0.49 & 0.40 & \mathbf{0 . 4 4 5}\end{array}$

In consequence, we decided to preserve the factors with low AVE values, accepting that as a limitation of our study.

\subsection{Structural Model}

After testing the structural model (Figure 2), we concluded that the model fit was very good: $\chi^{2}(311)=962.917, \mathrm{p}<0.01, \chi^{2} / \mathrm{df}=3.096, \mathrm{CFI}=0.950, \mathrm{TLI}=0.943, \mathrm{RMSEA}=0.057$, $\mathrm{SRMR}=0.065$.

By inspection of Table 4 below, we conclude that all our hypotheses are supported $(\mathrm{p}<0.01)$. One mediation effect can be spotted in our model: referral intention is a mediator between brand engagement and purchase intention. However, the mediation effect is not statistically significant, as assessed by the Sobel test $(\mathrm{SE}=0.016, \mathrm{z}=1.217, \mathrm{p}=0.223)$. These results will be discussed in detail in the next section.

\section{Figure 2}

Path coefficients

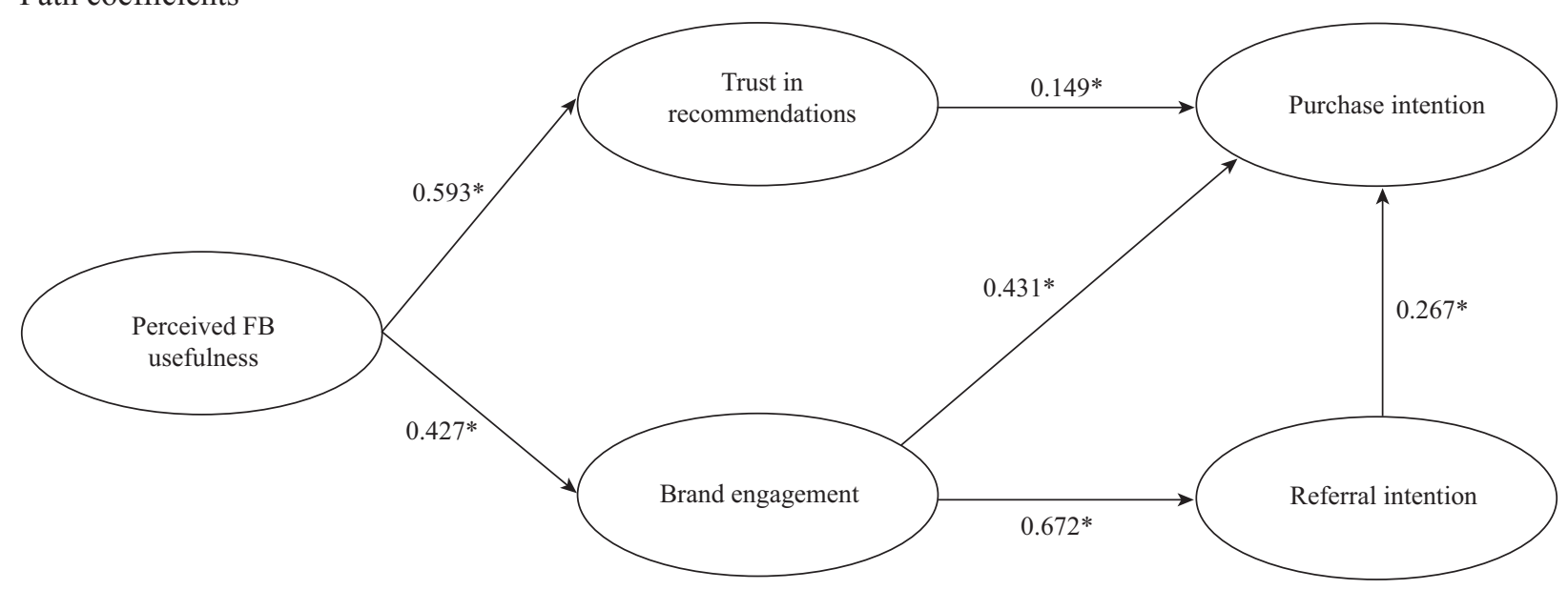


Table 4

Path coefficients of the structural model

\begin{tabular}{clclcr} 
Hypothesis & \multicolumn{3}{c}{ Path } & Loading & p \\
H1 & Perceived FB usefulness & $\rightarrow$ & Trust in recommendations & 0.593 & $<0.01$ \\
H2 & Perceived FB usefulness & $\rightarrow$ & Brand engagement & 0.427 & $<0.01$ \\
H3 & Trust in recommendations & $\rightarrow$ & Purchase intention & 0.149 & $<0.01$ \\
H4 & Brand engagement & $\rightarrow$ & Referral intention & 0.672 & $<0.01$ \\
H5 & Brand engagement & $\rightarrow$ & Purchase intention & 0.431 & $<0.01$ \\
H6 & Referral intention & $\rightarrow$ & Purchase intention & 0.267 & $<0.01$
\end{tabular}

\section{DISCUSSION}

Previous studies concerning the word of mouth in SNSs have primarily focused on the impact of brand engagement on word of mouth (Malciute \& Chrysochou, 2013) or on the influence of brand engagement on purchase loyalty (Turri, Smith, \& Kemp, 2013). However, they do not thoroughly investigate the antecedents of brand engagement and the influence of word of mouth on purchase intention. Our research fills these gaps. First of all, we have proved that both brand engagement and trust in recommendations are substantially influenced by the perceived usefulness of Facebook as a source of product recommendations. As expected, people who see Facebook as an environment where you can look for advice before buying a product or service will tend to trust their friends' recommendations and endorsements. The same people also have higher levels of brand engagement in this social network: they like (and subscribe to) brand pages to get news about their preferred brands, accept promotional messages from brands and share information about brands with other users.

Furthermore, brand engagement has a substantial impact on referral intention - in other words, on the propensity to spread word of mouth on Facebook $(B=.672)$. So people who follow their preferred brands online will tend to refer these brands to others by sharing information about them, by answering other people's questions and by getting involved in debates about the brands they like, sometimes defending them if necessary. So Facebook users with high brand engagement are probably the most effective influencers in the social network environment, and they could become authentic "advocates" or "ambassadors" of online brands.

Some interesting conclusions arise from investigating the effects on purchase intention. This intention is more or less influenced by three variables: trust in recommendations, brand engagement and referral intention. The influence of trust in recommendations is weak $(B=.149)$. From that we can draw the conclusion that Facebook users do not decide to buy just because of their friends' advice and suggestions. There are certainly other factors that will influence their buying decision - like price, convenience, packaging, brand trust, novelty, etc. In consequence, the chances that Facebook users would buy products from brands they do not know or like, just because their friends recommend those products, are pretty low.

Brand engagement has the strongest influence on purchase intention $(\mathrm{B}=.431)$. Therefore, people will be inclined to purchase the brands they actively watch on Facebook. This is not surprising: Facebook members who are interested in receiving information about brands would eventually buy and use the products of those brands, especially if they get an advantage (a discounted price, for example) or if they stumble upon an improved version of a product they already own.

Finally, a positive relationship between referral intentions and purchase intentions has been revealed. Nevertheless, this relationship is rather feeble $(B=.267)$. So people inclined to distribute 
information about brands on Facebook will not necessarily buy and use those brands themselves. Since the mediation effect of referral intention between brand engagement and purchase intention proved to be non-significant, we can conclude that the real influence on purchase intention is that of brand engagement. So people will buy products of a certain brand mainly because they really like that brand (that is why they follow its updates on Facebook, after all). Some of those people may also spread word of mouth about that brand and recommend it to their friends. However, just spreading word of mouth is not a guarantee of becoming an actual customer of the brand.

\section{LIMITATIONS AND FURTHER RESEARCH}

Our study has several limitations. First, the sampling method was a convenience sample, which often suffers from biases and may be less representative of the population being studied. Second, only Romanian Facebook users were investigated. Further studies may involve Facebook account holders from other countries as well.

The most important limitation is that some latent factors have low average extracted values (smaller than 0.5). Ping (2009) states that AVEs can be improved by dropping the individual items with large error variables. However, since our measurement model is stable enough (the path coefficients are highly significant) and discriminant validity is adequate, we decided to keep all the items in the model. At the same time, we admit that more measurement work may be needed for the latent variables with low AVEs; this could be done in future studies.

Further research could examine the effect of some moderating variables on eWOM intention and purchase intention. These moderators could be the type of product (e.g. physical product or service, utilitarian or hedonic), the type of referral message (e.g. rational or emotional), product involvement (high or low) and so on.

\section{CONCLUSIONS AND MANAGERIAL IMPLICATIONS}

In this study, brand engagement was found to be the key variable that affects both referral intention (i.e. word-of-mouth propensity) and buying propensity. Facebook users who follow the news about their favorite brands and are willing to accept communications from them will likely spread information about these brands to their peers (Facebook friends and fans). In its turn, brand engagement is strongly affected by the perceived usefulness of Facebook for getting product recommendations.

From our research point of view, Facebook members can be divided into two categories: those who do use Facebook as a primary source of information about products and services and those who do not. Our results show that members of the first category are foremost eWOM providers. A brand that seeks to build authority on Facebook should look for these people, convert them into fans and "feed" them with attention-grabbing information that is worth spreading. This way, most of the fans will provide free word-of-mouth advertising, becoming veritable brand influencers. The brand will obtain invaluable free exposure on these people's Facebook pages. Furthermore, an important segment of the fans will become actual customers, which is in fact the most important indicator of effective Facebook branding strategy.

\section{References}

Akar, E. \& Topçu, B. (2011). An examination of the factors influencing consumers' attitudes toward social media marketing. Journal of Internet Commerce, 10(1), 35-67. 
Alghamdi, M., Aldridge, C., \& Long, A. (2011). The influence of Facebook friends on consumers' purchase decisions. Postgraduate Day, p. 25.

Anderson, J. \& Gerbing, D. (1988). Structural equation modeling in practice: A review and recommended two-step approach. Psychological Bulletin, 103(3), 411-423.

Awad, N. \& Ragowsky, A. (2008). Establishing trust in electronic commerce through online word of mouth: An examination across genders. Journal of Management Information Systems, 24(4), 101-121.

Bickart, B. \& Schindler, R. (2001). Internet forums as influential sources of consumer information. Journal of Interactive Marketing, 15(3), p. 31.

Bughin, J., Doogan, J., \& Vetvik O.J. (2010). A new way to measure word-of-mouth marketing. McKinsey Quarterly, 2, 113-116.

Campbell, C., Ferraro, C., \& Sands, S. (2014). Segmenting consumer reactions to social network marketing. European Journal of Marketing, 48(3/4), 432-452.

Champoux, V., Durgee, J., \& McGlynn, L. (2012). Corporate Facebook pages: When "fans” attack. Journal of Business Strategy, 33(2), 22-30.

Chari, S., Christodoulides, G., Presi, C., Wenhold, J., \& Casaletto, J. (2016). Consumer trust in user-generated brand recommendations on Facebook. Psychology \& Marketing, 33(12), 1071-1081.

Cheung, C. \& Lee, M. (2012). What drives consumers to spread electronic word of mouth in online consumeropinion platforms. Decision Support Systems, 53(1), 218-225.

Chiosa, A.R. \& Anastasiei, B. (2015). The segmentation of Facebook users from Romania by WOM behavior. Annals of "Alexandru Ioan Cuza" University - Economy Series, 5, 160-9.

Cho, Y. \& Sagynov, E. (2015). Exploring factors that affect usefulness, ease of use, trust, and purchase intention in the online environment. International Journal of Management \& Information Systems (IJMIS), 19(1), p. 21.

Chu, S. \& Kim, Y. (2011). Determinants of consumer engagement in electronic word-of-mouth (eWOM) in social networking sites. International Journal of Advertising, 30(1), 47-75.

Davis, F. (1989). Perceived usefulness, perceived ease of use, and user acceptance of information technology. MIS Quarterly, 13(3), p. 319.

de Vries, L., Gensler, S., \& Leeflang, P. (2012). Popularity of brand posts on brand fan pages: An investigation of the effects of social media marketing. Journal of Interactive Marketing, 26(2), 83-91.

Fan, Y., Miao, Y., Fang, Y., \& Lin, R. (2013). Establishing the adoption of electronic word-of-mouth through consumers' perceived credibility. International Business Research, 6(3).

Flavián, C., Guinalíu, M., \& Gurrea, R. (2006). The role played by perceived usability, satisfaction and consumer trust on website loyalty. Information \& Management, 43(1), 1-14.

Fornell, C. \& Larcker, D. (1981). Evaluating structural equation models with unobservable variables and measurement error. Journal of Marketing Research, 18(1), p. 39.

Hamouda, M. \& Tabbane, R. (2013). Impact of electronic word of mouth evaluation on purchase intention. International Journal of Online Marketing, 3(2), 20-37.

Hassanein, K. \& Head, M. (2007). Manipulating perceived social presence through the web interface and its impact on attitude towards online shopping. International Journal of Human-Computer Studies, 65(8), 689-708.

Hsiao, K., Chuan-Chuan Lin, J., Wang, X., Lu, H., \& Yu, H. (2010). Antecedents and consequences of trust in online product recommendations. Online Information Review, 34(6), 935-953.

Hutter, K., Hautz, J., Dennhardt, S., \& Füller, J. (2013). The impact of user interactions in social media on brand awareness and purchase intention: The case of MINI on Facebook. Journal of Product \& Brand Management, $22(5 / 6), 342-351$.

Igbaria, M. (1995). The effects of self-efficacy on computer usage. Omega, 23(6), 587-605.

Jeong, E. \& Jang, S. (2011). Restaurant experiences triggering positive electronic word-of-mouth (eWOM) motivations. International Journal of Hospitality Management, 30(2), 356-366.

Karahanna, E. \& Straub, D. (1999). The psychological origins of perceived usefulness and ease-of-use. Information \& Management, 35(4), 237-250.

Keller, K.L. (2001). Building customer-based brand equity: A blueprint for creating strong brands. Marketing Science Institute.

Keller, K.L. (2009). Building strong brands in a modern marketing communications environment. Journal of Marketing Communications, 15(2-3), 139-155.

Liang, T., Ho, Y., Li, Y., \& Turban, E. (2011). What drives social commerce: The role of social support and relationship quality. International Journal of Electronic Commerce, 16(2), 69-90.

Lu, Y., Zhao, L., \& Wang, B. (2010). From virtual community members to C2C e-commerce buyers: Trust in virtual communities and its effect on consumers' purchase intention. Electronic Commerce Research and Applications, 9(4), 346-360.

Malciute J. \& Chrysochou, P. (2013). Customer brand engagement on online social media platforms: A conceptual model and empirical analysis. Paper presented at 42nd European Marketing Academy (EMAC). 
Mangold, W. \& Faulds, D. (2009). Social media: The new hybrid element of the promotion mix. Business Horizons, 52(4), 357-365.

McKnight, D., Choudhury, V., \& Kacmar, C. (2002). Developing and validating trust measures for e-commerce: An integrative typology. Information Systems Research, 13(3), 334-359.

Morgan-Thomas, A. \& Veloutsou, C. (2013). Beyond technology acceptance: Brand relationships and online brand experience. Journal of Business Research, 66(1), 21-27.

Morwitz, V., Steckel, J., \& Gupta, A. (2007). When do purchase intentions predict sales?. International Journal of Forecasting, 23(3), 347-364.

Newman, M. (2003). The structure and function of complex networks. SIAM Review, 45(2), 167-256.

Park, D. \& Kim, S. (2008). The effects of consumer knowledge on message processing of electronic word-of-mouth via online consumer reviews. Electronic Commerce Research and Applications, 7(4), 399-410.

Ping, R.A. (2009). Is there any way to improve Average Variance Extracted (AVE) in a Latent Variable (LV) X (Revised)?. Retrieved from http://www.wright.edu/ robert.ping/ImprovAVE2.doc

Pöyry, E., Parvinen, P., \& Malmivaara, T. (2013). Can we get from liking to buying? Behavioral differences in hedonic and utilitarian Facebook usage. Electronic Commerce Research and Applications, 12(4), $224-235$.

See-To, E. \& Ho, K. (2014). Value co-creation and purchase intention in social network sites: The role of electronic word-of-mouth and trust - A theoretical analysis. Computers in Human Behavior, 31, 182-189.

Smith, T., Coyle, J., Lightfoot, E., \& Scott, A. (2007). Reconsidering models of influence: The relationship between consumer social networks and word-of-mouth effectiveness. Journal of Advertising Research, 47(4), 387-397.

Soh, H., Reid, L., \& King, K. (2009). Measuring trust in advertising. Journal of Advertising, 38(2), 83-104.

Willemsen, L., Neijens, P., Bronner, F., \& de Ridder, J. (2011). "Highly recommended!" The content characteristics and perceived usefulness of online consumer reviews. Journal of Computer-Mediated Communication, 17(1), 19-38.

Wilson, E. \& Sherrell, D. (1993). Source effects in communication and persuasion research: A meta-analysis of effect size. Journal of the Academy of Marketing Science, 21(2), 101-112. 